\title{
Seroprevalence of bovine brucellosis and associated risk factors in and around Alage district, Ethiopia
}

\author{
Hagos Asgedom ${ }^{1}$, Delesa Damena ${ }^{1 *}$ and Reta Duguma ${ }^{2}$
}

\begin{abstract}
Brucellosis is a zoonotic disease with economic and public health impact, particularly for human and animal populations within developing countries that relay on livestock production. A cross sectional study was conducted between October 2013 and March 2014 in and around Alage district to determine the seroprevalence of bovine brucellosis and associated risk factors. A total of 804 sera samples; 421 from cattle managed under extensive production system and 383 from cattle managed under intensive production system were collected. Multistage cluster sampling method was employed to sample unvaccinated cattle above 6 months of age. Rose Bengal Plate Test and c-ELISA were used in serial for detection of antibodies against Brucella species. The overall seroprevalence was $2.4 \%$, and herd level seroprevalence was $45.9 \%$. A prevalence of 3.3 and $1.3 \%$ was recorded in the extensive and intensive farms respectively. Among the three sites, seropositivity of $3.4 \%$ in Naka, $3.3 \%$ in Negelewudisha and $1.3 \%$ in Alage were recorded. Risk factors such as age, sex, number of service per conception, calving interval and reproductive status were associated with serostatus of brucellosis. Taken as a whole, cattle in both intensive and extensive production systems are endemically infected by brucellosis at low level in the study areas. This warrants the need of integrated intervention strategies to minimize the spread of the disease in animals and reduce the risk of transmission to humans.
\end{abstract}

Keywords: Alage, Bovine brucellosis, Seroprevalence, Risk factors, Intensive and extensive farms

\section{Background}

Brucellosis is a highly contagious, zoonotic and economically important bacterial disease of animals worldwide and it is considered as one of the most widespread zoonoses in the world (Schelling et al. 2003). The disease in cattle, usually caused by Brucella abortus and occasionally by Brucella melitensis and Brucella suis, is characterised by late term abortion, infertility and reduced milk production (OIE 2008). Aborted foetuses and discharges contain large number of infectious organisms and transmit the disease within and in between herds. In addition, chronically infected cattle can shed lower numbers of organisms via milk and reproductive tract discharges, and can also vertically transmit infection to subsequently

\footnotetext{
*Correspondence: delesa_damenaa@yahoo.com

${ }^{1}$ National Animal Health Diagnostic and Investigation Center, P. O. Box 04, Sebeta, Oromia, Ethiopia

Full list of author information is available at the end of the article
}

born calves, and maintain disease transmission (McDermott and Arimi 2002). In dairy production, the disease is a major obstacle to the importation of high yielding breeds and represents a significant constraint to the improvement of milk production through cross breeding (Mustefa and Nicoletti 1993).

The epidemiology of cattle brucellosis is influenced by several factors including factors associated with disease transmission between herds, factors influencing the maintenance and spread of infection within herds (Crawford et al. 1990). Understanding the epidemiology of brucellosis is therefore, vital for strategizing evidence based disease control measures. However, such information is inadequate in sub-Saharan Africa. Consequently, appropriate preventive measures have not been undertaken in this part of the world (McDermott and Arimi 2002).

In Ethiopia, there is no documented information on how and when brucellosis was introduced and established. However, several serological surveys have showed 
widespread distribution of brucellosis in different livestock production systems (Dinka and Chala 2009). For instance, a seroprevalence of $2.4 \%$ in Jimma zone (Tolosa et al. 2008), $4.2 \%$ in south east Ethiopia (Bekele et al. 1999), $2.9 \%$ in central Oromia (Jergefa et al. 2009), $11.2 \%$ in east Showa zone (Hunduma and Ragasa 2009) $4.9 \%$ in Tigray region (Hileselassie et al. 2008) were documented.

However, these studies were geographically limited and didn't provide adequate information on risk factors that play role in occurrence and transmission of the disease. Particularly information is lacking in intensive farms although few scattered data are available. Therefore, the present study attempts to elucidate the sero-prevalence of brucellosis in intensive and extensive farms and assess associated risk factors in cattle in and around Alage district aiming at providing inputs for evidence-based disease control in Ethiopia.

\section{Methods}

\section{Description of the study area}

The present study was conducted in Alage Agricultural Technical and Vocational Education Training (ATVET) College and two surrounding Peasant associations (PAs). Negele Wudisha PA is located south west of Alage in Alaba district, Southern Nations and Nationalities regional state. Naka PA is located at North east of Alage in kombolcha district, Oromia regional state. The districts are situated at $217 \mathrm{kms}$ South West of Addis Ababa at longitude of $38^{\circ} 30^{\prime}$ East and altitude of $7^{\circ} 30^{\prime}$ North with an altitude of 1600 above sea level. The area is characterized by mild sub tropical climate with average minimum and maximum temperature of 11 and $29^{\circ} \mathrm{C}$ respectively. There are two defined rainy seasons: short rainy season (March-April), long rainy season (June-September). These two PAs have high cattle population compared to other PAs in the area. The total cattle population in both PAs is estimated to be 7, 550 (ARDOAD 2012).

\section{Study animals}

The ATVET Collage intensive production system consisted of four separate herds each containing more than 200 heads of cattle. Two of the farms contained Borana breeds and the remaining two herds contained Holstein cross breeds. The Holstein cross breeds are kept for milk production whereas the Boran breads are kept for fattening.

The extensive system consisted of Arsi cattle breeds reared under traditional small holder production system. In small holder farming, cattle form an integral part of the people's livelihood, provide a vital source of milk, meat, income, draught power for land tillage, transport and manure in addition to their use in numerous social and cultural roles. Cattle above 6 months of age including milking, none milking, replacement heifers and bulls were included in the study.

\section{Sample size and sampling strategy}

Herds were regarded as the primary sampling units and stratified according to the study area. In each study area, the approximate numbers of herds were listed with the assistance of local animal health office and community leaders. The herd was categorized into two groups based on the prevailing herd size in the study area as small $(<20)$ and large $(>20)$. Those herds that were reared in close proximity of each other (housed in consecutive barns and graze on the same field) were grouped together and considered as one although owned by different farmers. Only herds with a minimum of 10 cattle that were older than 6 months at the time of sampling were included in the study. The list of herds was obtained from animal health office and community leaders. Out of a total of 78 herds, 16 small herds and 17 large herds were randomly selected in both study districts; all the four intensive farms were sampled.

Based on previous validation studies, the diagnostic sensitivity and specificity of Rose Bengal Test (RBT) were assumed to be 90 and $75 \%$, respectively and for the competitive enzyme-linked immunosorbent assay (c-ELISA) 98 and $99 \%$, respectively (McGiven et al. 2003; Nielsen et al. 1995). Therefore, at individual animal-level, the combined sensitivity and specificity for RBT and the c-ELISA using a serial interpretation were calculated to be 88.2 and $99.8 \%$, respectively, as suggested by Noordhuizen et al. (1997). Based on these parameters, the sample size of individual cattle was estimated by using FreeCalc version 2 (Cameron 1999). Selection of cattle to be sampled from each herd was based on a systematic random sampling technique, where cattle were put in a crush pen and one animal was selected from five consecutive animals coming through the crush pen. A total of 804 cattle: 384 from the intensive farms and 420 from extensive farms were sampled.

\section{Sample and data collection}

Approximately $10 \mathrm{ml}$ amount of blood was taken aseptically from the jugular vein of each animal using plain vacutainer tubes and needles. Sera were kept at $-20^{\circ} \mathrm{C}$ in Alage ATVET animal health laboratory until serological tests were conducted. A questionnaire survey with open and closed questions was used amongst the owners whose animals were tested. The questions were specifically designed to get information from the animal owners and farm owners. The following data was collected on animal attributes: breed, sex, age, and reproductive status, stage of lactation, calving intervals and number of service per conception. Based on its biological relevance, age was stratified into 
three categories such as: $0.5-3,3-6$, and $>6$ years. The reproductive status was also categorized as heifer, pregnant, lactating and dry. Besides, information on farms such as: hygienic practices, herd size, and other managemental factors were collected. The presence of calving pens, waste (placenta, aborted material and dead animal) disposal methods was categorized into burying, open dump or feeding to dogs. Hygienic status of the farms was categorized as clean and not clean based on manure disposal, drainage and barn ventilation. Information about cause, symptoms, mode of transmission, prevention, and treatment was also collected to assess the awareness level of the farmers. Farmer's knowledge on brucellosis was assessed using twelve closed ended questions which were then reduced to five items using principal component analysis. The internal consistency of the variables were also checked (cronbach's $\alpha=0.837$ ). The respondents who scored above the mean rank were considered as having good knowledge about brucellosis and below mean rank were regarded as having poor knowledge.

\section{Rose Bengal Plate Test (RBPT)}

The Rose Bengal Plate Test was conducted at the National Animal Health Diagnostic and Investigation Center, Sebeta (NAHDIC) for screening positive samples. Positive sera were then retested using enzyme linked immuno sorbent assay (ELISA). Samples were considered as positive for brucellosis, if they were positive for both RBPT and ELISA. The RBPT procedure was followed based on the description by Nielsen et al. (1995).

\section{Competitive ELISA}

All RBPT positive sera were further tested using the SvanovirTM Brucella-Ab c-ELISA test kits (Svanova Biotech, Uppsala, Sweden) at NAHDIC. The test was performed according to the manufacturer's instructions. The test was conducted in 96-well polystyrene plate (Nalge Nunc, Denmark) that were pre-coated with Brucella species lipopolysaccharide (LPS) antigen. Serum diluted 1:10 was added to each well followed by equal volume of pre-diluted mouse monoclonal antibodies specific for a common epitope of the $\mathrm{O}$-polysaccharide of the smooth LPS molecule. The reactivity of the mouse monoclonal antibody was detected using goat antibody to mouse IgG that was conjugated to horseradish peroxidase. Hydrogen peroxidase substrate and ABTS chromagen were developed for $10 \mathrm{~min}$. The reaction was then stopped using $1 \mathrm{M} \mathrm{H}_{2} \mathrm{SO}_{4}$. Optical densities were read at $450 \mathrm{~nm}$ using Titertek Multiscan ${ }^{\circledR}$ PLUS reader (Flow Laboratories, UK). The threshold for determining seropositivity was based upon the manufacturer's recommendations (>30\%), with antibody titers recorded as percentage inhibition as defined by the ELISA kit supplier.

\section{Data analysis}

Data was entered into Microsoft (MS) Excel Spread Sheet program and statistical analysis was computed using Chi-square test and logistic regression using SPSS 19 window evaluation version. The total prevalence was calculated by dividing the number of RBPT and c-ELISA positive animals by the total number of animals that were tested. Herd level prevalence was calculated by dividing the number of herds with at least one reactor in RBPT and c-ELISA by the number of all herds tested. The association between risk factors and seropositivity to Brucella species was considered as significant at $\mathrm{P}<0.05$. Odds ratio (OR) was used to measure the degree of association between risk factors and seroprevalence of bovine brucellosis.

\section{Ethics approval}

All procedures were carried out according to the experimental practice and standards approved by the Animal Welfare and Research Ethics Committee at National Animal Health Diagnostic and Investigation Center (NAHDIC) that is in accordance with the international guidelines for animal welfare.

\section{Results \\ Occupational risk and awareness among farm works and farmers about brucellosis}

A total of 100 volunteer farm workers and herd owners were interviewed to assess the occupational risks and awareness levels. The majority of the participants in intensive farms were well aware of brucellosis. Up to $70 \%$ of the respondents were regarded as having good knowledge about brucellosis. The level of awareness was significantly lower $(\mathrm{P}=0.001)$ in extensive farms in which $78.3 \%$ of the participants were regarded as having poor knowledge of the disease (Table 1). The greater parts (82.5) of the respondents in intensive farms utilize basic PPE on farm activities. However, only one-fifth of the farmers in extensive farms use basic PPE although the majority $(78.3 \%)$ of them had the experience of assisting animals giving birth. Besides, $70 \%$ of the participants in intensive farms and up to $80 \%$ those in extensive farms responded that they have habit of drinking raw milk or eating raw meat as shown in Table 1.

In intensive farms, artificial insemination (AI) is used for breeding in herds with Holstein cross breeds and bull service is used in herds with Borana breeds. On the other hand, all herds in extensive farm use bull service for breeding. The farms in intensive farm were regarded as clean with good farm management practices. However, we observed poor hygienic practices including poor waste disposal, drainage and poor barn ventilation in the majority of the extensive farms. 
Table 1 Occupational risks and awareness among farm works and farmers about brucellosis in intensive and extensive farms in the study areas

\begin{tabular}{|c|c|c|c|c|}
\hline Variable & Intensive farms (n) & Extensive farms (n) & $X^{2}$ value & $P$ value \\
\hline \multicolumn{5}{|l|}{ Knowledge about brucellosis } \\
\hline Yes & 28 & 13 & & \\
\hline No & 12 & 47 & 23.18 & 0.00 \\
\hline \multicolumn{5}{|l|}{ Use of PPE } \\
\hline Yes & 33 & 12 & & \\
\hline No & 7 & 48 & 37.88 & 0.00 \\
\hline \multicolumn{5}{|l|}{ Assisted animals giving birth } \\
\hline Yes & 21 & 47 & & \\
\hline \multicolumn{5}{|l|}{ No } \\
\hline Habit of drinking raw milk or eating raw meat & 19 & 13 & 7.36 & 0.01 \\
\hline Yes & 28 & 48 & & \\
\hline No & 12 & 12 & 1.32 & 0.34 \\
\hline
\end{tabular}

\section{Seroprevalence of bovine brucellosis}

In the present study, a total of 804 cattle sera were collected from 33 herds and four intensive farms which were not vaccinated against bovine brucellosis. Of them, nineteen (19) sera were positive with both RBPT and ELISA tests. An overall animal level seroprevalence of $2.4 \%$ and herd level seroprevalence of $37.84 \%$ were recorded. There were no significant variations of the seroprevalence among different farms, PAs and production system as shown in Tables 2, 3, and 4 .

\section{Animal characteristics}

There was a significantly low seroprevalence $(0.4 \%)$ of bovine brucellosis in animals with less than or equal to 3 years old compared to animals with greater/equal to 7 years old $(5.3 \%, \mathrm{P}=0.019)$. The logistic regression result also showed that older animals were 11.4 times at higher risk than younger animals. Seropositivity in females $(3.4 \%)$ was significantly higher $(P=0.007)$ than that of males (0.4). The females were 1.15 times at higher risk than males (Table 5). Besides, association between brucellosis and reproductive status of the cows was statistically significant $(P=0.001)$ by taking heifers as a reference (Table 5). There were no significant differences in seropositivity between breeds or between farm-sizes (Table 5).

\section{Association of Brucella seropositivity with reproductive performances of animals}

Out of 29 animals that needed repeated services (more than or equal to three services), 10 cows (34.5\%) were seropositive for brucellosis. The logistic regression analysis indicated the strong association between brucella seropositivity and number of service per conception (NSPC) $(\mathrm{P}=0.001)$.

Similarly, there was association between calving interval and seropositivity to brucellosis $(\mathrm{P}=0.001)$. The seropositivity of cows that gave birth at an interval of 1 year, less/equal to 2 years and above 2 years were 2.1, 1.8 and $33.3 \%$ respectively. The Odd ratio of Brucella seropositivity in cows that gave birth above 2 years interval was 27.62 times higher than those cows calving yearly (Table 6).

\section{Discussion}

Knowledge and perception about brucellosis among farmers are crucial in controlling disease transmission. In this study, we interviewed farm workers and herd owners to assess their awareness levels about brucellosis and occupational risks using structured questionnaire. The participants in intensive farms were well aware of brucellosis. The majority $(70 \%)$ of the respondents were regarded as having good knowledge about brucellosis.

Table 2 Over all seroprevalence of bovine brucellosis in the intensive and extensive farms of the study area assessed by Chi-square

\begin{tabular}{lllllllll}
\hline Factor & Level & $\mathbf{n}$ & Test +ve & \% & OR & $\mathbf{9 5 \% ~ C l}$ & $\mathbf{X}^{\mathbf{2}}$ & $\mathbf{P}$ value \\
\hline Farm type & Intensive & 383 & 5 & 1.3 & & & & \\
& Extensive & 421 & 14 & 3.3 & 2.60 & $0.93-7.29$ & 3.54 & 0.06 \\
\hline
\end{tabular}


Table 3 Herd level seroprevalence of bovine brucellosis in intensive and extensive farms in the study area assessed by Chi square

\begin{tabular}{llccccccc}
\hline Factor & Level & $\mathbf{n}$ & Test +ve & \% & OR & $\mathbf{9 5} \%$ Cl & $\mathbf{X}^{\mathbf{2}}$ & P value \\
\hline Farm type & Extensive & 33 & 14 & 42.4 & & & & \\
& Intensive & 4 & 3 & 75 & 4.07 & $0.38-43.38$ & 1.52 & 0.22 \\
\hline
\end{tabular}

Table 4 Seroprevalence of bovine brucellosis in three different sites in the study area assessed by logistic regression

\begin{tabular}{llllllll}
\hline Factor & Level & $\mathbf{n}$ & Test +ve & \% & OR & 95 \% Cl & P value \\
\hline \multirow{2}{*}{ Sites } & Alage $^{\mathrm{a}}$ & 383 & 5 & 1.3 & - & - & - \\
& Negele Wudisha & 246 & 8 & 3.3 & 2.54 & $0.82-7.86$ \\
& Naka & 175 & 6 & 3.4 & 2.68 & $0.81-8.92$ & 0.105 \\
\hline
\end{tabular}

${ }^{a}$ In reference to

Table 5 Association between animal characteristics and seropositivity of Brucella assessed by logistic regression and Chisquare

\begin{tabular}{|c|c|c|c|c|c|c|c|c|}
\hline Factors & Level & $\mathrm{n}$ & Test +ve & $\%$ & OR & $95 \% \mathrm{Cl}$ & Z-test & $P$ value \\
\hline \multirow[t]{3}{*}{ Age } & $0.5 \leq 3^{\mathrm{a}}$ & 233 & 1 & 0.4 & & & & \\
\hline & $3 \leq 6$ & 308 & 4 & 1.3 & 3.2262 & $28.32-30.53$ & 1.0386 & 0.299 \\
\hline & $\geq 7$ & 263 & 14 & 5.3 & 11.376 & $90.33-85.47$ & 2.3308 & 0.0198 \\
\hline \multirow[t]{2}{*}{ Sex } & $F^{a}$ & 529 & 18 & 3.4 & & & & \\
\hline & M & 275 & 1 & 0.4 & 0.104 & $0.014-0.78$ & -2.3742 & 0.007 \\
\hline \multirow[t]{3}{*}{ Breed } & $\operatorname{Arsi}^{a}$ & 494 & 16 & 3.2 & & & & \\
\hline & $\mathrm{HF}$ & 149 & 1 & 0.7 & 0.1724 & $0.302-3.75$ & -1.3915 & 0.1641 \\
\hline & Boran & 161 & 2 & 1.2 & 0.4001 & $2.02-4.15$ & -0.8571 & 0.3914 \\
\hline \multirow[t]{2}{*}{ Herd size } & $\leq 20^{\mathrm{a}}$ & 232 & 6 & 2.3 & & & & \\
\hline & $>20$ & 572 & 13 & 2.6 & 1.6378 & $4.30-5.28$ & 0.3586 & 0.7199 \\
\hline
\end{tabular}

a Others were computed in reference to this category

We also demonstrated good hygienic practices; including separate calving rooms, use of clean water, regular cleaning of barns, proper waste disposal and use of PPE. The farm workers were regularly trained on biosafety practices by college instructors. Good knowledge about brucellosis has been shown to have a protective effect towards animal and human infections in Kyrgyzstan (Kozukeev 2003).

In contrast to this, the awareness level of the farmers was significantly lower in extensive farms. The majority $(78.3 \%)$ of the farmers were regarded as having poor knowledge. We also observed poor hygienic practices and uncontrolled animal movements. These could pose high risks of transmitting the disease within and in between the herds. This is in agreement with previous studies in extensive livestock production system in Ethiopia (Ragassa et al. 2009; Megersa et al. 2011). In addition to this, only one-fifth of the farmers in extensive farms use basic PPE although a big proportion (78.3 \%) of them had the experience of assisting animals giving birth. The occurrence of brucellosis in humans is associated with contact with domestic animals (Alballa 1995), exposure to aborted animals and assisting animal parturition (Cooper 1992; Kozukeev et al. 2006). In this study, the majority of the participants in both types of farms have the habit of drinking raw milk or eating raw meat. Prevalence of brucellosis in humans is attributed to the culture and tradition of consuming raw milk and milk products (Omore et al. 1999).

The present study showed that the overall seroprevalence of bovine brucellosis in Alage and its surrounding was at low level $(2.4 \%)$. In extensive management system, a prevalence of $3.3 \%$ was recorded. This is in agreement with the previous studies in different parts of Ethiopia in which a disease prevalence ranging from 1.5 to $3.5 \%$ were reported (Megersa et al. 2011; Asmare et al. 2010; Berhe et al. 2007). However, the present result is lower than the reports of earlier studies in Abernosa 
Table 6 Association between Brucella seropositivity and reproductive performance of cattle in the study area assessed by logistic regression

\begin{tabular}{|c|c|c|c|c|c|c|c|c|}
\hline Factors & Level & $\mathrm{n}$ & Test + ve & $\%$ & OR & $95 \% \mathrm{Cl}$ & Z-test & $P$ value \\
\hline \multirow[t]{3}{*}{ NSPC } & $1^{\mathrm{a}}$ & 262 & 2 & 0.8 & & & & \\
\hline & 2 & 82 & 5 & 6 & 8.3974 & $41.96-46.23$ & 2.5147 & 0.011 \\
\hline & $\geq 3$ & 29 & 10 & 34.5 & 62.053 & $303.4-311.55$ & 5.0546 & 0.000 \\
\hline \multirow[t]{3}{*}{ Calving interval } & $1 \leq 2$ years $^{\mathrm{a}}$ & 218 & 4 & 1.8 & & & & \\
\hline & 1 years & 48 & 1 & 2.1 & 8.609 & $0.005-0.351$ & 3.0178 & 0.003 \\
\hline & $>2$ years & 33 & 11 & 33.3 & 27.622 & $0.011-0.127$ & 84.683 & 0.000 \\
\hline \multirow[t]{4}{*}{ Reproductive status } & Heifer $^{a}$ & 85 & 1 & 1.2 & & & & \\
\hline & Lactating & 140 & 2 & 1.4 & 0.821 & $0.073-9.20$ & & 0.87 \\
\hline & Dry & 107 & 4 & 3.7 & 2.68 & $0.481-9.91$ & 1.8413 & 0.26 \\
\hline & Pregnant & 148 & 11 & 7.4 & 5.54 & $1.21-25.46$ & -1.996 & 0.028 \\
\hline
\end{tabular}

${ }^{\text {a }}$ Others were computed in reference to this category

cattle breeding ranch and East shoa where a seroprevalence of 19.5 and $11.5 \%$ was reported by Yirgu (1991) and Dinka and Chala (2009) respectively. This study also showed a very low seroprevalence $(1.3 \%)$ of brucellosis in the intensive production system. This is in consistent with previous a study in and around Addis Ababa (Tefera 2006). On the other hand, higher seroprevalence ranging from 8.11 to $38.7 \%$ were recorded in intensive production systems located in different parts of Ethiopia (Rashid 1993; Sintaro 1994; Gebremariam 1985). The observed disparity could be attributed to various factors including differences in testing protocols, cattle rearing systems, and herd size.

In the present study, a statistically significant association between sex and seroprevalence of brucellosis was observed. Almost all (94.7 \%) of the seropositive animals were females. This result was in agreement with earlier studies in Ethiopia where absence of male seroreactors was reported (Berhe et al. 2007; Tolosa 2004). The present study also showed the presence of statistically significant associations between age and seropositivity of brucellosis. This finding was supported by a previous report from Ethiopia (Asmare et al. 2010). Growth stimulating factors for Brucella organisms become abundant when the animal becomes sexually matured (Radostits et al. 2007). Besides, higher prevalence of brucellosis in older cattle can be attributed to the constant exposure of the cattle over time to the agent.

Very high seropositivity $(33.3 \%)$ was observed in cows which gave birth above 2 years interval in the current study. This is supported by earlier reports from Ethiopia (Musa et al. 1990; Hileselassie et al. 2008). The possible reason could be the effects of the disease on reproductive tract causing retained fetal membrane that usually leads to uterine infection and hence poor conception rate.
The present study also revealed the existence of strong association between number of services per conception and seropositivity of brucellosis. This finding is in agreement with a previous study (Bekele et al. 1999). The number of services per conception increases when cattle are repeatedly experience abortion, retained fetal membrane, dystocia and other reproductive health problems.

Likewise, a statistically significant association between pregnancy and seropositivity of Brucella was observed in this study. This is in line with a previous report from Ethiopia (Hileselassie et al. 2008). This could be explained by the fact that, erythritol sugar in the placenta and fetal fluid is elevated during gestation period. This stimulates the growth and multiplication of the bacteria in the reproductive organs (Walker 1999). The bacterial load often reduced in months following calving and abortion until the next pregnancy (Coetzer and Tustin 2004; Radostits et al. 2007).

In epidemiological studies, the use of two tests applied serially is recommended to maximize the accuracy of test results (Godfroid et al. 2002). A combination of RBT and c-ELISA or CFT tests is the most widely used serial testing scheme. RBT is highly sensitive test and could easily applied in field conditions whereas, c-ELISA is highly specific usually used as a confirmatory test method (Samui et al. 2007). The combination of these tests in this study could therefore maximize the accuracy of the findings.

Brucellosis is continues to be a major public and animal health problem in Ethiopia. However, there is no national control scheme in place because of economic seasons and lack of information about the disease status at national level (Megersa et al. 2011; Yohannes 2013). Therefore, it is necessary to devise and implement an integrated disease control approach involving inter-sectorial collaborative 
strategies between animal and human health sectors, nongovernmental and governmental institutions to minimize the burden of the disease.

\section{Conclusions}

It is evident that brucellosis is endemic at low prevalence level in Ethiopia. In this study, we found a very low level seroprevalence at individual animal level in both extensive and intensive farms. However, a high herd level prevalence was recorded in both types of farms; indicating the wide spread distribution of the disease in the area. Factors such as age, sex, calving interval, number of service preconception and reproductive status were associated with seropositivity of Brucella species. This study provides important information on epidemiology of brucellosis in cattle in the study areas and highlights the need for implementation of control measures and raising public awareness on zoonotic transmission of brucellosis.

\section{Authors' contributions}

HA designed the project collected data, analyzed the data and drafted the manuscript. DD contributed in drafting and thoroughly revising the manuscript. RD supervised the project. All authors read and approved the final manuscript.

\section{Author details \\ ${ }^{1}$ National Animal Health Diagnostic and Investigation Center, P. O. Box 04, Sebeta, Oromia, Ethiopia. ${ }^{2}$ Department of Clinical Studies, College of Veteri- nary Medicine and Agriculture, Addis Ababa University, P. O. Box 34, Bishoftu, Oromia, Ethiopia.}

\section{Acknowledgements}

The authors wish to express their gratitude to Alage Agricultural Technical Vocational Education Training Collage, Addis Ababa University and National Animal Health Diagnostic and Investigation Center for financing this work and providing technical assistance.

\section{Competing interests}

The authors declare that they have no competing interest whatsoever that could have influenced the results of this study in any manner.

Received: 1 February 2016 Accepted: 8 June 2016

Published online: 23 June 2016

\section{References}

Alballa SR (1995) Epidemiology of human brucellosis in southern Saudi Arabia. J Trop Med Hyg 98:185-189

ARDOAD (2012) Agricultural and Rural Development Office of Alage District annual report. pp 25-28

Asmare K, Asfaw Y, Gelaye G, Ayelet G (2010) Brucellosis in extensive management system of Zebu cattle in Sidama Zone, Southern Ethiopia. Afr J Agric Res 5(3):257-263

Bekele A, Molla B, Asfaw Y, Yirgu L (1999) Bovine brucellosis: seroepidemiologoical study in selected farms and ranches in South Ethiopia. Bull Anim Health Prod 48:13-17

Berhe G, Belihu K, Asfaw Y (2007) Sero-epidemiological investigation of bovine brucellosis in extensive cattle production system of Tigray region of Ethiopia. Int J Appl Res Vet Med 5:65-71

Cameron AR (1999) Survey toolbox-a practical manual and software package for active surveillance of livestock diseases in developing countries. In: ACIAR monograph series, no. 54. Australian Centre for International Agricultural Research, Australia
Coetzer JW, Tustin RC (2004) Infectious disease of live stock, vol 3, 3rd edn. South Africa Oxford University Press, Cape Town, pp 1507-1551

Cooper CW (1992) Risk factors in transmission of brucellosis from animals to humans in Saudi Arabia. Trans R Soc Trop Med Hyg 86:206-209

Crawford RP, Huber JD, Adams BS (1990) Epidemiology and surveillance. In: Nielsen K, Duncan JR (eds) Animal brucellosis. CRC Press Inc., Boca Raton, pp 131-148

Dinka H, Chala R (2009) Sero prevalence study of bovine brucellosis in pastoral and agro-pastoral areas of East Showa zone, Oromia Regional State, Ethiopia. Am Eurasian Agric Environ Sci 6:508-512

Gebremariam K (1985) Prevalence of brucellosis in four different farms around Addis Ababa. DVM, Thesis, FVM, Addis Ababa University, Ethiopia

Godfroid J, Saegerman C, Wellemans V, Walravens K, Letesson JJ, Tibor A, McMillan A, Spencer S, Sanna M, Bakker D, Pouillot R, Garin-Bastuji B (2002) How to substantiate eradication of bovine brucellosis when a specific serological reactions occur in the course of brucellosis testing. Vet Microbiol 90:461-477

Hileselassie M, Shewit K, Moses K (2008) Serological survey of bovine brucellosis in barka and arado breeds of Western Tigray, Ethiopia. Prev Vet Med 94:28-35

Hunduma D, Ragasa C (2009) Seroprevalence study of bovine brucellosis in pastoral and agro pastoral areas of East Showa Zone, Oromia Regional State, Ethiopia. Am Eurasia Agric Environ Sci 6:508-512

Jergefa T, Kelay B, Bekana M, Teshale S, Gustafson H, Kindah H (2009) Epidemiological study of bovine brucellosis in three agro ecological areas of Central Oromia, Ethiopia. Rev Sci Tech 28:933-943

Kozukeev TB, Ajeilat S, Maes E, Favorov M, Centers for Disease Control, Prevention (CDC) (2006) Risk factors for brucellosis—Leylek and Kadamjay districts, Batken Oblast, Kyrgyzstan, January-November, 2003. MMWR Morb Mortal Wkly Rep 55(Suppl 1):31-34

Kozukeev TB, Maes E, Favorov M, Centers for Disease Control and Prevention (CDC) (2006) Risk factors for brucellosis_Leylek and Kadamjay districts, Batken Oblast, Kyrgyzstan. MMWR Suppl 1:31-34

McDermott JJ, Arimi SM (2002) Brucellosis in Sub-Saharan Africa: epidemiology, control and impact. Vet Microbiol 20:111-134

McGiven JA, Tucker JD, Perret LL, Stack JA, Brew SD, MacMillan AP (2003) Validation of FPA and cELISA for the detection of antibodies to Brucella abortus in cattle sera and comparison to SAT, CFT, and iELISA. J Immunol Methods 278:171-178

Megersa B, Biffa D, Niguse F, Rufael T, Asmare K, Skjerve E (2011) Cattle brucellosis in traditional livestock husbandry practice in Southern and Eastern Ethiopia, and its zoonoticimplication. Acta Vet Scand 53:24. http://www. actavetscand

Musa MT, Jahans KL, Fadalla M (1990) Clinical manifestations of brucellosis in cattle of the Southern Darfur Province, Western Sudan. J Comp Pathol 103:1

Mustefa M, Nicoletti P (1993) FAO, WHO, OIE guidelines for regional brucellosis control program for the Middle East, Amman, Jordan

Nielsen KH, Kelly L, Gall D, Nicoletti P, Kelly W (1995) Improved competitive enzyme immunoassay for the diagnosis of bovine brucellosis. Vet Immunol Immunopathol 46:285-291

Noordhuizen JP, Frankena K, van der Hoofd CM, Graat EA (1997) Application of quantitative methods in veterinary epidemiology. Wageningen Pers, Wageningen, pp 31-62

OIE (2008) World Organization for Animal Health. Manual of diagnostic tests and vaccines for terrestrial animals. http://www.oie.int/ international-standard-setting/terrestrial-manual/access-online

Omore AO, Muriuki H, Kenyanjui M, Owango M, Staal SJ (1999) The dairy subsector: a rapid appraisal: research report of the MoA/KARI/ILRI smallholder dairy project, Nairobi. International Livestock Research Institute, Nairobi

Radostits OM, Gay CC, Hinchcliff KW, Constable PD (2007) Veterinary medicine: a textbook of the diseases of cattle, horses, sheep, pigs and goats, 10th edn. Saunders Elsevier, London

Ragassa G, Mekonnen D, Yamuah L, Tilahun H, Guta T, Gebreyohannes A, Aseffa A, Abdoel TH, Smits HL (2009) Human brucellosis in Traditional pastoral communities in Ethiopia. Int J Trop Med 4:59-64

Rashid M (1993) Reproductive wastage in cattle due to bovine brucellosis. In: Institute of Agricultural Research editor. Proceedings of the fourth national livestock improvement conference, Addis Ababa, pp 270-272 
Samui KL, Oloya J, Munyeme M, Skjerve E (2007) Risk factors for brucellosis in indigenous cattle reared in livestock-wildlife interface areas of Zambia. Prev Vet Med 80:306-317

Schelling E, Diguimbaye C, Daoud S, Nicolet J, Boerlin P, Tanner M, Zinsstag J (2003) Brucellosis and Q-fever sero prevalence of nomadic pastoralists and their livestock in Chad. Prev Vet Med 61:279-293

Sintaro T (1994) The impact of brucellosis on productivity on an improved dairy herds of Chaffa state farm, Ethiopia. M.Sc. Thesis Fuchburg Veterina medizinerei University

Tefera M (2006) Study on bovine brucellosis in cattle slaughtered at Addis Ababa and Sululta with focus on occupational hazard. M.Sc. Thesis, FVM Addis Ababa University, Debre-Zeit, Ethiopia

Tolosa T (2004) Seroprevalence study of bovine brucellosis and its public health significance in selected sites of Jimma Zone, Western Ethiopia. M.Sc. Thesis. Addis Ababa University, Faculty of Veterinary Medicine, Debre Zeit
Tolosa T, Regassa F, Belihu K (2008) Seroprevalence study of bovine brucellosis in extensivemanagement system in selected sites of Jimma Zone, Western Ethiopia. Bull Anim Health Prod Afr 56:25-37

Walker LR (1999) Brucella. In: Wight D, Hirsh C, Yuan Chung Z (eds) Veterinary microbiology. Blackwell Science, Hoboken, pp 196-202

Yirgu T (1991) Seroepidemiological survey of bovine brucellosis at Abernosa DVM Thesis, FVM, Addis Ababa University, Ethiopia

Yohannes M, Degefu H, Tolosa T, Belihu K, Cutlerand R, Cutler S (2013) Brucellosis in Ethiopia. Afr J Microbiol Res 7(14):1150-1157

\section{Submit your manuscript to a SpringerOpen ${ }^{\circ}$ journal and benefit from:}

- Convenient online submission

- Rigorous peer review

- Immediate publication on acceptance

- Open access: articles freely available online

- High visibility within the field

- Retaining the copyright to your article 